\title{
Ambiguities and Potentialities of Social Sciences in the Peruvian Mining Context
}

Emmanuelle Piccoli and Isabel Yepez del Castillo

\section{CpenEdition}

\section{Journals}

Electronic version

URL: http://journals.openedition.org/anthropodev/435

DOI: 10.4000/anthropodev.435

ISSN: 2553-1719

\section{Publisher}

APAD - Association pour l'anthropologie du changement social et du développement

\section{Printed version}

Date of publication: 1 July 2016

Number of pages: $31-53$

ISBN: 797-10-93476-03-2

ISSN: 2276-2019

\section{Electronic reference}

Emmanuelle Piccoli and Isabel Yepez del Castillo, «Ambiquities and Potentialities of Social Sciences in the Peruvian Mining Context », Anthropologie \& développement [Online], 44 | 2016, Online since 01 January 2017, connection on 01 May 2019. URL : http://journals.openedition.org/anthropodev/435 ; DOI : 10.4000/anthropodev.435

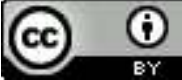

La revue Anthropologie \& développement est mise à disposition selon les termes de la Licence Creative Commons Attribution 4.0 International. 


\section{Ambiguities and Potentialities of Social Sciences in the Peruvian Mining Context}

Emmanuelle Piccoli and Isabel Yepez del Castillo'

L'article montre les tensions, ambiguïtés et potentialités d'un travail en sciences sociales dans une situation de conflit autour d'industries extractives au Pérou. La première partie $d u$ texte donne des informations relatives aux politiques extractives au Pérou, aux tensions sociales grandissantes et à l'augmentation de la criminalisation de la protestation sociale; nous présentons à ce titre le cas du conflit minier Conga. La deuxième partie analyse la place des sciences sociales dans le contexte extractif péruvien. Nous soulignons que le rôle des chercheurs en sciences sociales en tant que spécialistes des conflits sociaux est en augmentation ces dernières années; nous montrons pourquoi la neutralité $n^{\prime}$ est pas plausible dans les conflits impliquant des mégaentreprises minières et de quelle manière la production du savoir peut être extrêmement ambiguë. Finalement, la troisième partie du texte présente certaines potentialités des recherches engagées. Nous discutons l'idée d'un positionnement "amphibie" entre l'Académie et les mouvements sociaux (Svampa, 2008). Nous montrons également l'importance de confronter les "politiques de résignation" (Benson et Kirsch, 2010). Nous soulignons finalement l'importance d'attirer l'attention vers l'émergence et les alternatives. Cette discussion s'appuie sur le cadre théorique de la "sociologie des émergences" (De Sousa Santos, 2011).

This article will show the tensions, ambiguities and potentialities faced by social scientists in a situation of

\footnotetext{
${ }^{1}$ We want to thank Peter Frost and Timothy Thomson for their assistance with the manuscript and our colleagues and reviewers for their useful comments.
} 
conflict around extractive industries in Peru. The first section provides background information on extractive politics in Peru, associated with growing social tensions and increasing criminalization of social protest. Within this general scenario, a particular case will be presented, the Conga mining conflict, an outstanding example of major challenges posed by the social response to extractive policies. The second section addresses the roles played by social sciences in this context, with a focus on the increasing involvement of social scientists as conflict analysts and solvers. We will also argue the near-impossibility of intellectual neutrality while approaching conflicts spurred by large-scale mining and that the peril of ambiguity looms over the production of knowledge on the social roots and contexts of these conflicts. The third and final section deals with the potentialities of engaged research. We will discuss the benefits of an "amphibious" positioning between Academy and broader civil society (Svampa, 2008), show the importance of confronting the "politics of resignation" (Benson and Kirsch, 2010) and underline the importance of drawing attention to the "sociology of emergences" (De Sousa Santos, 2011) with full consideration of alternatives as critical means to reconcile a broad diversity of epistemologies.

\section{Introduction}

In April 2015, a social researcher argues once more on a widely broadcast Peruvian TV show that a national and international complot, orchestrated by an "anti-mining network" akin to terrorist networks, composed of NGOs, human right activists and social scientists, threatens Peruvian development and attempts to destroy the economic model of the country.

In this context of escalating conflict and tensions between those supporting development at all cost and those decrying the longterm irresponsibility of such policies, being a social scientist poses significant questions. Indeed, not only have political imageries and economic stakes ceased to be extraneous to Academia but they 
have also become two of its integral components, profoundly shaping its intellectual perspective. This article, as part of a special issue on the challenges and potentialities of engaged research in social science, will ponder some of the elements of this situation, such as the political imagery associated with resource development in Peru and the place and roles of the social sciences in such a context, and then explore possible paths to engage in the debate.

The first section of the article will shortly present the extractive policies in Peru. We will also illustrate how these economic policies, heavily based on extractive practices, rely on the criminalization of protest and the disqualification of opposition discourses. We will focus on the Conga mining conflict as a basis for our analysis of the challenges posed by this scenario.

The second section will analyze the place of social science in this context. We will show how the role of social scientist as "conflictologists" (specialists in social conflicts and their resolution) has grown in recent years and will argue the near-impossibility of neutrality in a context of economies heavily reliant on large-scale resource extraction. Concomitantly, we will highlight the ambiguities faced by the production and diffusion of social knowledge as a consequence of the involvement of social scientists in these environments.

Finally, the third section will discuss the potentialities offered by engaged research. We will discuss the potential benefits and risks derived from an "amphibious" positioning between Academia and broader civil society. We will also defend the importance of confronting what Peter Benson and Stuart Kirsch (2010) call the "politics of resignation". We will finally underline the importance of integrating emergences and alternatives into all relevant aspects of social analysis, taking as a reference framework the "Sociology of emergences" proposed by Boaventura De Sousa Santos (2011).

Although we base our analysis on our own field work research (using data produced by mining companies and opposition groups, such as publications, propaganda and reports as well as personal interviews with the actors, especially from the critical side), the 
main purpose of this article is to propose an epistemological discussion on the role played by social sciences in a context of mining capitalism.

In a previous article, we dwelt on the necessity of a more comprehensive and critical perspective on extractive conflicts and proposed a more balanced epistemological perspective for social sciences in mining conflict contexts (Mujica Bermudez and Piccoli, 2014). Here, our aim is to address some of the underlying challenges of that research program by offering a few concrete epistemological propositions. We hope that these, as partial and limited as they may be, will prove useful to other social scientists with research interests in related conflicts or in epistemologies of the South.

Resource extraction and criminalization of protest in Peru

In recent years, the development of natural resources has been central to Peru's national economic policy. Minerals, oil and timber have been attracting many transnational corporations that wish to invest in a country whose environmental and social standards are propitious in terms of pro-fit. These projects are not being carried out in empty territory but in areas inhabited, lived in, used and shared by people who, while having varying positions toward these new economic actors, have been radically affected by the projects. The result is a growing number of polarizations and tensions (Arellano Yaguas, 2011; Bebbington, 2007 and 2013; Diez et al., 2009), an outstanding example of which is provided by the conflict over the Conga mine project, in the Cajamarca region (Piccoli, 2015).

\section{The resource development model and the multiplication of conflicts}

Since the 1990s and subsequent to Alberto Fujimori's administration, the legal environment for resource development has become more relaxed, thereby favoring the establishment of 
megaprojects in several regions of the country and the granting of "concessions" for mineral or oil and gas development over nearly two-thirds of the national territory. Al-though a concession does not necessarily imply automatic resource deve-lopment, its legal structure empowers the central government to make all of the decisions that eventually lead to such development.

In 2014, for the whole country, mining concessions covered 25.9 million hectares ( $20 \%$ of the national territory). Oil and gas concessions covered over 68 million hectares in 2009 (around 53\% of the national territory) (Cooperacción, 2009; Finer and Jenkins, 2012). In the Cajamarca region, concessions cover $40.55 \%$ of the departmental territory. In addition to Yanacocha and Conga, several other megaprojects are being deve-loped or in the planning stage, including Zanja, Tantahuatay, Cerro Corrona, Galeano, Michiquillay, and Sipan.

The same year, the Peruvian Defensoria del Pueblo (Ombudsman) re-gistered 276 social conflicts, 168 of which were linked to environment conflicts and 119 to mining-related issues (Defensoria del Pueblo, 2014: 96). The Conga mine project in Cajamarca has been one of the most pro-minent conflicts in recent years in Peru, largely because the local populations have managed to mount an organized resistance that has attracted national and international attention.

\section{The Conga case}

In 2011, major conflict broke out over plans to expand the Yanacocha gold mine (run by Colorado-based Newmont Mining) by means of the Conga project. It has been denounced as a serious threat to the large aquifer in the area where the mine is scheduled to operate and the corresponding Environmental Impact Assessment (EIA) (Knight Piésold Consultores, 2010) has been criticized for its partiality and deficient risk analysis. In attempts to balance the official EIA, several technical documents have been issued addressing relevant issues missing in the EIA and presenting data that support the high likelihood of occurrence of the many 
threats associated with the project (Colegio de ingenieros del Perú, Concejo departamental de Cajamarca, 2011; Lambán Jiménez, 2011; Ministerio del Ambiente, 2011; Moran, 2011). Even a governmentissued report emphasizes outstanding deficits in the Conga project EIA (Fernández Rubio, Lopez Garcia and Martins Carvalho, 2012).

Popular mobilization against Conga began in November 2011, when the Department of Energy and Mines approved the project EIA, a key step ushering the implementation of the project. A broadspectrum mobilization that included the "Defence Fronts" (Frentes de Defensa), teachers' union, peasant organizations - such as the peasant patrols or Rondas Campesinas (Piccoli, 2011) -, and Regional Government (De Echave and Diez, 2013) manifested opposition to this decision by taking to the streets as well as the lakes directly affected by the project. This opposition movement also resorted to the law (notably by appealing to the Constitutional Court and the Inter-American Court of Human Rights), to seek technical assessment from independent experts, or to express itself in the form of art. "Conga" became a nation-wide symbol of the anti-mining struggle in the country and the first major conflict of the Ollanta Humala administration. Attempts were made at "dialogue" between central government representatives and opposition groups. The talks, however, focused on how to implement the project, without contemplating the alternative option of halting the project altogether, the primary demand by the people. Given these premises, it was not a surprise that no constructive proposals crystallized from these talks. As a consequence of this failure to advance in the understanding and recognition of all positions, public unrest remained strong and, in response, the President of the Republic resorted twice to force, sending in the army and declaring a state of emergency in order to quell demonstrations. A tragic development of these events was the death of five demonstrators in the hands of the army in July 2012.

A sobering conclusion is that, instead of creating a space for debate about decision-making processes that bear upon future generations, the protests have tended to polarize this space to a 
high degree. Particularly in Cajamarca, individuals and groups have had to choose sides, as stated by a citizen:

"In the town, there are the 'for' and the 'against,' the 'proconga' and the 'anticonga.' Business people have created their own lob-bying group 'in favor of development'. Everything is now highly polarized between 'yes' and 'no'" (a citizen interviewed by us in July 2013).

Accusatory discourse portrays defenders of the environment as "opponents of development" instead of recognizing their key role in protecting a territory. In sum, what could be a joint debate on how to build a healthy, sustainable and sufficiently prosperous future has turned into a confrontation, mainly due to the unwillingness of authorities to consider positions on the long-term future of the region other than those imposed by the global mining industries and economies. In other words, political and economic choices extraneous to the region have generated a new divide among local inhabitants, justified by a priority to defend the investments of the shareholders of the involved companies.

In their various roles and positions, project opponents use a diversity of avenues through which to channel their challenges to the Conga project, although they have difficulties to receive official acceptance of their stance. In the five years of opposition to Conga, the most effective actions to make some dent on the official position to reject any reconsideration of the project have been the street protests and the picketing around the lakes. However, such mobilizations are harshly repressed and members of the opposition remain under continuous surveillance, reinforced by a continued and pervasive deployment of the army and the police (whose wages are supplemented by the mining company).

\section{Criminalization of social protest}

As part of the process followed by the authorities to curb the opposition to Conga, those who challenge the establishment in the region of a resource company are also criminalized. If not directly linked to terrorism as mentioned in the introduction, positions 
critical with the project are attributed in the media to ignorance, dismissively associated with Andean life. In contrast, public space is hardly accessible to dissent.

One of the clearest expressions of these constraints is the declaration of the state of emergency, which prevents any public mobilizations promoted by opposition forces. The accompanying repression has been extremely violent in several occasions, causing five deaths. We note that the decision by the government to declare the state of emergency does not find justification in any acts of violence committed by the project opponents and thus can be explained as a purely repressive response aimed at silencing opposition (Silva Santisteban, 2015; CNDDHH, DHSF, GRUFIDES, APA, 2013).

Criminalization of dissent also takes the form of words and representations, at times dehumanizing and humiliating, that portray "the other" as an inferior being. These characterizations emanate from the highest spheres of the State.

A 2007 article by former President Alan García illustrates his perception of native populations (Piccoli, 2009). Under the title "EI perro del hortelano" - literally, "The dog of the vegetable garden", which may be translated into English as "The dog in the manger" (Bebbington, 2012: 8) - he discusses resource development by multinational corporations in Amazonia and the ensuing inevitable conflicts with local populations. In the article, Alan García likens the Amazonian native population to "dogs" who do not let the rest of the nation benefit from resources that they themselves are not using. Implicit in this discourse is the image of the "dog in the manger". The argumentation relies on the questioning the status of citizen of indi-genous people, as in colonial time and disqualifying "the other" construct as a separate and remote entity.

Furthermore, the official sanctification of the development discourse justifies a widespread and watchful inquisition, intent on harshly chastising the sacrilege of its questioning, both militarily (state of emergency) and symbolically (in portrayals of reality). Thus, when groups of citizens - in this case Amazonian and Andean 
- oppose resource development projects, their opposition efforts are not accepted as valid challenges to existing policy, with rejection, delegitimation and criminalization of any proposal to incorporate alternative views into policy making.

Places and roles of the social sciences in resource extractive contexts

Large-scale mining projects, as a major source of conflicts, are becoming paramount social sciences study subjects in Peru. So prevalent is this current focus that the term "conflictologist" (conflictólogo) has been coined to refer to social scientists working on social conflicts surrounding the industrial exploitation of natural resources.

As required by the understanding of a region, social sciences follow the most important topics of actuality in the region, but this leads to two main questions. First, because social sciences are used by corporation and the state as instrument of "pacification", which generally means imposition of mining projects, and then, because of the imbalance of production of knowledge between corporation and their critics. We also need to highlight the fact that no neutrality is possible in such conflictive contexts.

\section{The instrumentalization of social sciences}

Two principal dynamics foster the recent ascent of instrumental social sciences in Peru, in processes tightly linked to resource development. On the one hand, the extractive companies and the Government have a strong interest in gathering data on social movements: they analyze their organization, social foundations, interactions and modus operandi to afford a sound understanding of their functioning and thus more effectively neutralize them. On the other hand, social sciences, as academic disciplines, are also keenly interested in resource conflict situations as spaces in which they can update their analytical tools and test their hypotheses. 
Market logic applied to social sciences has turned them into instruments to garner information to control strategic spaces for economic development projects. "Instrumental" social sciences are thus understood primarily as an array of technical knowledge and methodological tools that serve some practical purpose, in the case under consideration to further the development models based on resource extraction, through the minimization of the risks that local populations reject and jeopardize the application of such models (Mujica Bermudez and Piccoli, 2014). More specifically, social sciences research can provide critical knowledge and elements to be used, either by extractive companies or the State, for the control and repression of opposition movements, concealed behind rhetoric of "conflict prevention" and "dialogue".

As a consequence, jobs in resource extractive companies (oil and gas companies in the Amazonian region and mining companies in the Andes) have become the foremost career openings for graduates in social scien-ces, in particular anthropologists, who used to be an important workforce in the NGO sector. This is a major change in Peru, as Espinosa de Rivero stresses in the case of Amazonian field:

"Some used to work in projects related to NGOs or indigenous organizations defending rights and interests of indigenous groups. Nevertheless, the majority was involved with Amazonian groups through social or development projects promoted by the State as well as national and international NGOs. Finally, in the lasts years, a growing number of colleagues accepted jobs in the Amazon within private corporations, mainly hydrocarbon corporations, but also in tourism or in consultancy firms bringing services to corporations or State" (Espinosa de Rivero, 2011: 389)².

In a 2012 report dubbed "Willaqniki" ("The one who sounds the alert" in Quechua), the President of Peru's Council of Ministers (Prime Minister) presented the National Office for Dialogue and Sustainability, whose goal is to understand and, above all, prevent

${ }^{2}$ Translations by the authors. 
conflicts as effectively as possible. Conflicts are seen as expressions of a misunderstanding that can always be ironed out through negotiation. The document clearly states that:

"By gathering primary information it becomes possible to obtain detailed identification of the social and political actors of social orga-nizations, of the attitudes of the population, and of investment projects, among other things, so that it will be easier to prepare statistics periodically on conflict potential and dialogue in the country. Similarly, this information points to possible ways to plan preventive actions and solutions to social conflicts" (Presidencia del Consejo de Ministros, 2012: 41).

From an instrumental perspective, it is important to study the relationships between mining companies and the local population perceptions, behaviors, and social settings - solely "to avoid conflicts" and to favor economic development. The goal is to reduce investment risks by learning about others and by discovering the rationality that gives shape to the life of native or peasant communities. Thus, the ultimate goal is to ensure unopposed, conflict-free development. In situations like the Conga conflict, pacification implies - in such perspective - favoring or creating public opi-nion states that help buttress the confidence of private investors to continue with the companies' proposals even in the face of widespread opposition. As such, instrumental social sciences interventions are far from being neutral or in pursuit of an ideal common good.

Instrumental social sciences can also ultimately contribute to a feeling of resignation that another world is neither possible nor about to become possible. First, by focusing exclusively on the differentiation of points of view between actors, the rhetoric of conflict may prevent the recognition of a problem, the elements that originate such conflict. This approach limits the analysis to the tip of the iceberg. Second, the basic premise of the instrumental social sciences is that resource development and asso-ciated industries must be taken for granted. Social scientists with narrow perspectives of reality (the local conflict, without taking in account 
global inequalities) contribute indirectly to the legitimation of mining activities and to prevent the eradication of the sources of inequality in local power.

\section{The implausible neutrality}

In the above context of polarization, neutrality is an illusion fraught with ambiguity, as pointed out by Stuart Kirsch:

"Neutrality may not be possible in disputes between transnational corporations and indigenous communities because of structural ine-qualities that make it easier for corporations to take advantage of anthropological expertise and silence opposing voices" (Kirsch, 2002: 22).

From an observer's viewpoint, neutrality may only be possible if contending parts are roughly balanced in power. In cases of extreme inequality, the likelihood of abuse of dominant positions is too strong to

be ignored. In this perspective, claims of neutrality from social scientists may be a misrepresentation of the fact that, in reality, their studies contribute to further shift the balance in favor of the positions held by mining companies.

It is also fundamental to consider that any position, including that of "scientific neutrality" towards politics, becomes political. One has only to leaf through a Government report such as the above-mentioned "Willaqniki", where we learn the official position that knowledge of controversies and conflicts is key to eliminating the consequences without addressing the root problem, assuming the perspective of those intent on imposing a development model based on large-scale resource extraction (Presidencia del Consejo de Ministros, 2012).

In Cajamarca, as the conflict unfolded and grew, social researchers began to face increasingly pressing questions about their stance with regard to the two sides in the conflict. They could not avoid getting trapped in the tangled mesh that characterizes the extreme polarization of the region. Given the unequal power relationships, a declaration of "neutrality" or "being in the middle" 
was interpreted as a position that would accept the possibility of a "yes, but...," i.e. "yes" to resource development "but" only under stricter rules of social responsibility and environmental standards. Such a position of seeming conditional acceptance of resource development, encouraged by the central Government, far from being considered "neutral", has been massively rejected by the population of Cajamarca and denounced as "pro-mine."

A further aspect that merits critical examination concerns the uses and misuses of language. In the specific case of the use by corporations of a language characteristic of social and natural sciences, the idea of "neutrality" and "objectivity" as unavoidably stemming from the use of "scientific language" is frequently propagated in order to disguise a positioning on the side of corporations. As Stuart Kirsch argues, the claim that only "scientific language" is synonymous of truth, as opposed to the use of emotive language, is employed by corporations to dismiss their critics (Kirsch, 2014: 157) and, by extension, to challenge the scientific validity of studies and reports produced by the critical side.

Contrary to claims of "neutrality" and "objectivity" in the "science" produced for or by corporations, many independent analyses have repea-tedly demonstrated systematic and serious deficiencies in such reports, raising the question whether they can be considered real science. The Conga project Environmental Impact Assessment, a document in scientific language that contains numerous and outstanding technical flaws, illustrates that the inherent goal of "corporate science" is not to produce objective knowledge but to use technical tools and language to support and justify predetermined decisions, intentionally blind to any discordant data or analysis, in an approach that constitutes the very opposite of true science (Moran, 2011).

This use of "neutrality" and "science" to justify imposition has impacts on the perception that the public has of social scientists. In 
such a context, presenting oneself as "neutral" may turn into an unwanted liability.

\section{The ambiguity of the production of knowledge}

The difficulty experienced by social sciences to remain neutral in situations of conflict developed around profound baseline inequalities is also translated as a major ambiguity related to the intended or unintended uses that may be given to the increasing volume of research data collected and analyzed.

In spite of the increasing allure of job opportunities associated with instrumental social sciences, many social scientists continue to have a ge-nuine academic interest in the study and understanding of social movements and dissent in places like Cajamarca, in attempts to decipher the cultural, social, anthropological and political bases of a seemingly successful opposition movement (responsible for maintaining the Conga project blocked four years after the initiation of open resistance). However, the attraction exerted by this case on well-intended intellectuals has brought in unanticipated inconveniences. For example, an NGO actively involved in the Conga conflict is being forced to reject applications by numerous gra-duate and undergraduate students to participate in thesis projects to study the Conga conflict under the NGO's umbrella. In their own words, "Instead of working, we would be just looking after them without obtaining anything in return". Thus, an imbalance is created whereby, on the one hand, the sole role expected from members of critical groups like this NGO is to become informants for other social scientists while, on the other hand, the demand to directly collaborate with them is so strong that they are forced to turn down students and researchers. Although these circumstances may translate into increased visibility and prestige among intellectual circles of critical associations actively engaged in situations of conflict, it also results in an excessive burden, inevitably accompanied with a diversion of resources away from the core objectives of these organizations. 
A further aspect needs to be considered that impinges upon the ambiguities inherent in social sciences research on a priori lopsided conflicts. Even though many social scientists, out of personal affinity, may prefer to study, and side with, opposition movements, an unintended outcome of their research - that is likely to rebound against those same movements - is a dissemination of detailed information on the composition, structure and strategies of opposition movements that will be used by the other side in the conflict as tools to undermine them. This can create a trap for researchers that want to position themselves close to social movements but may finally provide information that may be more likely used by corporation against these movements. Even if these investigators do not intend to favor mining corporations, an imbalance can be created by the very diffusion of this knowledge in English and using a specialized language, readily accessible to corporations and their paid technical experts but much less so to popular or grassroots opposition movements.

In sum, these ambiguities represent dilemmas for social scientists, who are led to intellectual or ethical traps with no satisfactory resolution.

Potentialities and challenges of engaged researches in a mining context

In addition to the illusion of neutrality, an illusion of engagement with social movements may be at work that does not necessarily lead to a positioning of the researcher towards specific side in the conflict under study.

Engagement can be polysemic. Hagberg and Ouattara (2012) refer to engagement as a methodological obligation for the anthropologist, driven by participation and empathy. In our case, we will use the term from a more "political" or "public" perspective. In the following discussion, a social scientist is engaged when he/she takes a position in the public debate, based on personal 
fieldwork experience. We will thus more specifically refer to the term engaged in the sense of "public engagement".

In this section, we will turn our attention to the engagement of social scientists in situation like the Conga mine conflict. We will underline the potentialities of an amphibious position (Svampa, 2008) and, at the same time, the difficulties faced by committed researchers. Subsequently, we will consider the proposal by Peter Benson and Stuart Kirsch (2010) to become engaged from a different perspective, namely by reversing the focus and conducting a parallel ethnography of corporate actors. Finally, we will also examine the importance, for social science, to be prospective and to undertake a sociology (and anthropology) of emergences (De Sousa Santos, 2011).

\section{Activism as reciprocity in critical situations and the} potentialities of an amphibious positioning

Beyond performing research involving data collection and analysis, social researchers, studying social movements and opposition groups situations of conflict, are also privileged witnesses of the needs and hardships incurred by the subjects of their study, including structural inequalities, threats to informants and criminalization. It is not surprising that, in these circumstances, sociologists and anthropologists may feel inclined, as individuals, to position themselves with one of the sides of the conflict, generally the underdog or the weaker side. When intellectual positioning is followed by active engagement, a critical boundary can be crossed such that the researcher becomes, simultaneously, an inside participant observer and a wider political actor of the situation under study. As such, the critical and engaged researcher is bound to experience hardships and cri-minalization to extents that may approximate those undergone by the subjects of his or her study.

A more nuanced interpretation of positioning and engagement in situations of conflict is defended by Maristella Svampa (2008), who urges researchers to transcend their stance of expert neutrality 
- a contradictory position, as argued above - just as they should transcend the stance of activist researchers who have entirely merged with their subjects of study. In her proposal, researchers should instead adopt a stance she calls "amphibious". Amphibious researchers are characterized by their ability to transit from one space to another and, in the process, to gain a better ability to understand and reflect upon social realities, their personal positions, and their own societies of origin, in addition to developing multiple ties of solidarity and creating hybrid realities (Svampa, 2008: 31).

This proposition seems a very fertile one, as it underlines the utility of social science for social movements as "knowledge for action", where each part acts from a predetermined condition (producing knowledge, acting as social movement). The underlying purpose is to extend the diffusion of knowledge such that it is no longer restricted to academic circles but rather intended to reach the broader society, in particular social movements. The proposition advocates a more democratic possession of knowledge and its practical application requires a capacity to shift languages as the researcher wades between academic and social contexts. We note, however, that for such a stance to be effective, the existence of common grounds and interests between the amphibious researcher and the social movements under study is a prerequisite. Of necessity, this limits the choice of topics that may be investigated, which may discourage some researchers from adopting Svampa's proposition.

As a further consequence of becoming "embedded" within the social or grassroots movements under study, the researcher may be requested to play specific roles on their behalf that clearly exceed a stance as a mere observer. For example, the researcher may be requested to act as a spokesperson for the group or as a conveyor of information to other groups or associations. This level of involvement may turn into a conflict in cases in which contradictions arise between the researcher's own political and ethical positions and those of the social group. Thus, the adoption of a prudent attitude is advisable before committing too earnestly 
to roles involving such a level of engagement: first, because of the need to gain a profound understanding of the likely complex relationships between different social movements and their supporting networks as well as their short- and long-term goals and ideological backgrounds; and, second, because of the risk of jeopardizing the position of the researcher as an independent observer.

These considerations lead to imply that the clarification of the researcher's motivations to investigate a subject is more important than ever (Olivier de Sardan, 2008: 165-208). Further, one needs to consider the influence exerted on the perspective by the researcher of the conflict under study as a function of the specific local environment in which he or she becomes embedded (for example, peasant organizations vs. pro-mining associations), which may be conducent to significantly different conclusions.

As briefly hinted above, however, a major practical concern associated with active engagement is not methodological or epistemological, but the physical and psychological integrity of the committed and actively engaged researcher, who becomes the target of criminalization and harassment. As witnessed in Cajamarca (2011-2015), this takes the form of letters of inti-midation, house break-in (without robbery, which makes common theft an unlikely motivation), sabotage of automobiles, and even the rape of persons closely related to the researcher in unusual circumstances. Therefore, to work in association with critical NGOs or opposition groups can be dangerous and thus generate fear to the point of functioning as a deterrent for other researchers inclined to follow similar paths.

\section{On the importance of a broader analysis and a shift of perspective}

At the intersection of the needs for broad analyses and reflexivity,

Peter Benson and Stuart Kirsch advocate the development of an anthropology that shifts its object of study to pay: 


\begin{abstract}
"[...] greater anthropological attention to the exercise of corporate power and, in particular, the strategies corporations use in response to their critics and how this facilitates the perpetuation of harm" (Benson and Kirsch, 2010: 459).
\end{abstract}

Such a shift in attention should help provide sound arguments to challenge the "politics of resignation" which too often afflicts social scientists and other civil society actors, and turn it into a "basis of transformative politics" (Benson and Kirsch, 2010). As such, resignation is not extraneous to situations of conflict sparked by resource development whereby corporations have co-opted environmental discourses to improve the public image of their own position, enabled by the recruitment of social researchers at their service. These researchers, trapped in unequal power relationships, exert resignation and cynicism (Kirsch, 2014: 159-187). According to these two authors, the determined energy dedicated by companies to dismiss criticisms or, at best, to cosmetically adapt to them has demoralized social scientists as citizen-authors, and this discouragement merits analysis. To counteract resignation, Benson and Kirsch (2010) propose to reverse the customary analysis by dissecting the policies that create false impressions of inevitability, as opposed to taking for granted the frameworks that are presented to the analyst as inevitable.

In this perspective, it may be less urgent to analyze the social actors of a local conflict between corporations, the State and peasants than to scrutinize and show how these policies are constructed and what forms of power are causal forces in the conflicts. This can be done by devoting far more academic attention than hitherto to corporations, including mining companies, thus providing data and analyses to better understand the principles and mechanisms that drive the corporate-State side of resource development. This information should be important both to promote a more complete comprehension of such conflicts from an academic viewpoint and also for an improved grasp by social movements of the motivations, strategies and tools of the other side in the conflict. By applying this approach, social research can 
actively contribute to a more balanced flow of knowledge and thus partially reduce the vast inequalities that character-rize these conflicts.

\section{An engagement reliant on changing the possible future}

Social research, that seeks a committed perspective and questions the use of "the dog in the manger" metaphor to foster exclusions and the unanimity with which the development and modernization perspectives are promoted, can be equipped with additional approaches. A major reason why it is so difficult to resist the politics of resignation is an absence of diffusion of other possible futures as credible and attainable alternatives. In order to fill this outstanding gap, Boaventura De Sousa Santos (2011) proposes a program based on what he designates a "Sociology of emergences", anchored in the thinking of the Global South, that complements, and departs from, Western critical tradition. He seeks to highlight existing avenues for change and their potential for building a future other than that shaped by "lazy reasoning", a weak reasoning that characterizes the discourse associated with the promotion of development. His quest is as much political as epistemological as he targets both colonialism and capitalism with new analytical perspectives that originate from the South and notably from indigenous logics.

The "Sociology of emergences" is defined by this Portuguese sociologist as "an investigation into the alternatives contained in the horizon of possibilities" (De Sousa Santos, 2011: 37). In other words, he is not content with showing what is contained in the present and rather strives to reveal a future with unexpected possible scenarios. He aims to replace the emptiness of a future based on a linear time with a future of plural and concrete possibilities, which are simultaneously utopian and realistic, to be constructed in the present. Therefore, his proposal extends the field of possible and plausible social experiences.

These two forms of sociology open the door to conceiving a future beyond pre-built frames of analysis: in the case of Peru, they 
pave the road to a new understanding of the present and future of resource development in the country. De Sousa Santos (2011) advocates the application of analytical rigor that surpasses official formulations and categorizations, such as "pro-mine vs. anti-mine" or "conflict management". He is inviting us to look at the creative potential of present movements and their capability to bring about and affirm a different future where mining, oil and gas development would have a truly secondary role.

In the case of Cajamarca and the Conga conflict, the application of this principle would imply a reliance on peasant perspectives on territories and to accept and interiorize their value and complexity. To offset the multiplication of widespread media positioning that judge peasants as "savages", "non-logical" and "uneducated" to disqualify their worldview, anthropologists have the responsibility to understand and transmit the non-techno-scientific perspectives on the land and their inherent logics. This implies a conscious effort to grasp the value, meaning and logic of the local narrative and imageries that depict the territories, the place and importance of water and the living environment, shared by respondents with the researcher doing fieldwork, and accept their intrinsic relevance as a valid perspective of the world. By embracing this knowledge, the researcher will be better positioned to comprehend the fundamental logic that underlies the rejection of large-scale mining which, far from ignorance, represents the expression of a full and meaningful speech, and a genuine demand for political participation, recognition of equal citizenship and respect. Recognition of this world is a recognition that at stake is much more than a mere "conflict to solve". As such, an acceptance of the importance of these emergences serves to counteract the politics of resignation by directing mindsets and efforts towards the consideration of potential alternatives rather than to pessimistic criticism (De Sousa Santos, 2011), thus broadening intellectual perspectives of social scientists and contributing to a democratic evolution of political perspectives. 


\section{Conclusion}

This article has presented some of the ambiguities and potentialities associated with carrying out engaged social sciences in Peru, in a context of conflicts linked to large-scale mining, in which the increased criminalization of social protest, repression, disqualification of discourses and exclusion of indigenous populations has resulted in an increase in the complexity of the roles played by social sciences.

Social research is always subjected to be used as an instrument of social control, either as a direct goal of the analysis, or as a repurposing of information gathered with other aims. A major objection to this instrumentalization resides in the inequality of the situation, such that an analysis of the balance of power rapidly shows that peasants and indigenous population are in a position where their rights and expressions are not democratically guaranteed. Is the social scientist supposed to ignore such a situation of inequality while participating in the gathering of information and analysis of data that can be subsequently employed to reinforce the existing inequality?

Although the recognition of the illusion of neutrality is not new to social sciences, it is particularly pertinent to research conducted on mining conflicts in Peru. The complexity of such situations, however, causes that a positioning of the researcher alongside social movements, may not suffice to direct the production of knowledge that is supportive of those movements. An engaged position involves additional steps by the social scientist, in trying to address the ambiguities fraught by the production of knowledge on actors that are under surveillance, and in a clarification of their epistemological and political analysis.

We believe that the alternative modes of engagement we proposed here can be relevant in the broader Peruvian context. Adopting an "amphibious positioning" between the academia and social movements would facilitate the transfer of knowledge (Svampa, 2008) and enhance the ne-cessary scrutiny towards 
corporations through anthropological and sociological analysis (Kirsch, 2014). Doing so, we call for an anthropology of emergences (De Sousa Santos, 2011), with a renewed focus on perceptions of reality.

These three positions suggest individual as well as collective orientations. As such, universities in Peru could be key places to discuss these possibility of an alternative focus on mining conflict, especially as new masters in Anthropology are being created. Today, the concern about job opportunities for their students may drive professors to push towards an instrumental use of anthropological knowledge. The overall purpose of this article was precisely to call for an alternative epistemological basis, ope-ning a necessary discussion on the plurality of social sciences in Peru.

\section{References}

ARELLANO YAGUAS J., 2011, ¿Minería sin fronteras?: conflicto y desarrollo en regiones mineras del Perú, Lima, IEP-PUCP-UARM, $324 \mathrm{p}$.

BEBBINGTON A., 2013, Industrias extractivas, conflicto social y dinámicas institucionales en la región andina, Lima, IEP-CEPES-GPC Grupo Ciudadania, $440 \mathrm{p}$.

BEBBINGTON A., 2012, Social Conflict, Economic Development and Extractive Industry: Evidence from South America, London/New York, Routledge, $256 \mathrm{p}$.

BEBBINGTON A., 2007, Minería, movimientos sociales y respuestas campesinas, Una ecología política de transformaciones territoriales, Lima, IEP-CEPES, $349 \mathrm{p}$.

BENSON P., KIRSCH S., 2010, "Capitalism and the Politics of Resignation", Current Anthropology, 51: 459-486.

COOPERACCION, 2009, Mapas de concessiones del Peru, [online], visited 17/02/2013, http://www.cooperaccion.org.pe/NACIONAL.html

CNDDHH, DHSF, GRUFIDES, APA, 2013, Policía mercenaria al servicio de las empresas mineras, La responsabilidad de Suiza y del Perú en las 
violaciones de derechos humanos en conflictos mineros, Lima, GRUFIDES, APA, $40 \mathrm{p}$.

COLEGIO DE INGENIEROS DEL PERÚ, CONCEJO DEPARTAMENTAL DE CAJAMARCA, 2011, Informe: 'Revisión preliminar del estudio hidrológico e hidrogeológico del estudio de impacto ambiental del proyecto minero Conga', Cajamarca, Colegio de ingenieros del Perú/Concejo departamental de Cajamarca, 35 p.

DE ECHAVE J., DIEZ A., 2013, Más allá de Conga, Lima, RedGE Cooperaccion, $156 \mathrm{p}$.

DE SOUSA SANTOS B., 2011, "Epistémologies du Sud », Etudes Rurales, 187: 22-48.

DEFENSORIA DEL PUEBLO, 2014, Decimoctavo Informe Anual de la Defensoría del Pueblo, Lima, Defensoria del Pueblo, 372 p.

DIEZ A., DE ECHAVE J., HUBER L., REVESZ B., LAMATA X. R., TANAKA M., 2009, Minería y conflicto social, Lima, IEP-CIPCA-CBC-CES, 428 p.

ESPINOSA DE RIVERO O., 2011, “La antropología amazónica en el Perú y su relación con el movimiento indígena", in CHAUMEIL J.-P., ESPINOSA DE RIVERO O., CORNEJO C. M., Por donde hay soplo, Estudios amazónicos en los países andinos, Lima, IFEA-Fondo editorial PUCP-CAAP-Centre EREA du LESC: 377-396.

FERNÁNDEZ RUBIO R., LOPEZ GARCIA L., MARTINS CARVALHO J., 2012, Dictamen Pericial Internacional; Componente hídrico del Estudio de Impacto Ambiental del Proyecto Minero Conga (CajamarcaPerú), Lima: Presidencia del Consejo de Ministros.

FINER M., JENKINS C.N., 2012, "Proliferation of Hydroelectric Dams in the Andean Amazon and Implications for Andes-Amazon Connectivity", PLOS ONE, 7(4), [online], doi:10.1371/journal.pone.0035126

HAGBERG S., OUATTARA F. 2012, "Engaging anthropology for development and social change", Bulletin de I'APAD, 34-36 [online], visited 15/12/2015, apad.revues.org/4105

KIRSCH S., 2014, Mining Capitalism, The Relationship between Corporations and Their Critics, Berkeley, University of California Press, $314 \mathrm{p}$. 
KNIGHT PIÉSOLD CONSULTORES, 2010, Resumen Ejecutivo del Estudio de Impacto Ambiental del Proyecto Conga, [online], visited 27/12/2015, www.scribd.com/doc/76664906/

LAMBÁN JIMÉNEZ L. J., 2011, Comentarios Generales sobre el Estudio Hidrogeológico Presentado en la Evaluación del Impacto Ambiental Del Proyecto Conga, [online], visited 27/12/2015, www.scribd.com/doc/84491008

/Comentarios-Generales-sobre-el-Estudio-Hidrogeologico-delProyecto-Conga

MINISTERIO DEL AMBIENTE, 2011, Informe № 001-2011. Comentarios al Estudio de Impacto Ambiental del proyecto CONGA aprobado en octubre de 2010, Lima, MINAM, [online], visited 27/12/2015, http://e.gestion.pe /128/doc/0/0/4/3/9/439159.pdf

MORAN R., 2011, The Conga Mine, Peru: Comments on the Environmental Impact Assessment (EIA) and Related Issues, [online], visited 27/12/2015, http://fr.scribd.com/doc/84560844/ComentariosAl-EIA-Py-Conga

MUJICA BERMUDEZ L., PICCOLI E., 2014, «L'anthropologie en terrain minier. Réflexions sur les pratiques professionnelles des anthropologues au Pérou en contexte d'exploitation des ressources naturelles ", in BREDA C., CHAPLIER M., HERMESSE J., PICCOLI E., Terres (dés) humanisées : ressources et climat, Louvain-la-Neuve, Academia: 79-104.

OLIVIER DE SARDAN J.-P., 2008, La rigueur du qualitatif: Les contraintes empiriques de l'interprétation socio-anthropologique, Louvain-laNeuve, Academia Bruylant, $368 \mathrm{p}$.

PICCOLI E., 2015, «Pérou-Justice et citoyenneté dans les Andes péruviennes: histoire et rôle des Rondes paysannes en contexte minier ", Dial, revue mensuelle en ligne, vol. 3314, [on line], visited 19/03/2015, www.alterinfos.org/spip.php?article6715

PICCOLI E., 2011, Les Rondes paysannes. Vigilance, politique et justice dans les Andes péruviennes, Louvain-la-Neuve, Academia, $170 \mathrm{p}$.

PICCOLI E., 2009, « Amazonie péruvienne : Le pétrole et le sang ou la sève et les hommes? Réflexions autour des violences de Bagua (5 juin 
2009) et des mécanismes d'actions internationales de solidarité ", En question, $90:$ 4-7.

PRESIDENCIA DEL CONSEJO DE MINISTROS, 2012, Willaqniki, Informe de diferencias, controversias y conflictos sociales, $\mathrm{n}^{\circ} 1$, [online], visited 03/08/2014, http://www2.pcm.gob.pe/popup_PCM/willaqniki.pdf

SILVA SANTISTEBAN R., 2015, "La difamación como análisis político", La Republica [online], visited 07/04/2015, www.larepublica.pe/columnistas/kolumna-okupa/la-difamacioncomo-analisis-politico-07-04-2015

SVAMPA M., 2008, Cambio de Epoca. Movimientos sociales y Poder Político, Buenos Aires, Siglo XXI: $236 \mathrm{p}$.

\section{$\operatorname{siviviven}$}

Emmanuelle Piccoli, Laboratoire d'anthropologie prospective et Centre d'études du développement, Université catholique de Louvain

E-mail : emmanuelle.piccoli@uclouvain.be

Isabel Yepez del Castillo, Centre d'études du développement,

Université catholique de Louvain

E-mail : isabel.yepez@uclouvain.be 